\title{
The Effect of Bauxite Residue on the Avoidance Behavior of Enchytraeus albidus (Enchytraeidae)
}

\author{
Ivett Kriszta Kerekes ${ }^{1 *}$, Viktória Feigl ${ }^{1}$ \\ ${ }^{1}$ Department of Applied Biotechnology and Food Science, Faculty of Chemical Technology and Biotechnology, \\ Budapest University of Technology and Economics, H-1111 Budapest, Múegyetem rkp. 3, Hungary \\ * Corresponding author, e-mail: ivett.kerekes@mail.bme.hu
}

Received: 13 July 2018, Accepted: 28 August 2018, Published online: 30 October 2018

\begin{abstract}
The potworm Enchytraeus albidus has been used as a testorganism to assess the effects of soil polluting chemicals. The current standardized test methods do not exploit the sensitivity of avoidance behavior of the animals towards chemicals as measurement endpoint. In this paper we tested the effect of bauxite residue (BR), the waste from alumina production, on the habitat of a macrodecomposer in three different soils: an acidic sandy soil (NY), a carbonated sandy soil (OB) and a silty soil (NH). In the acute toxicity tests the testing of whole soil samples proved to be more sensitive compared to the testing of soil suspensions and soil extracts, which indicated significant mortality only at over $50 \% \mathrm{BR}$ in soil. $\mathrm{EC}_{20}$ values were $9 \% \mathrm{BR}$ in $\mathrm{OB}, 28 \% \mathrm{BR}$ in $\mathrm{NH}$ and $34 \% \mathrm{BR}$ in NY in the whole soil tests of our study. In the avoidance test potworms chose the $1 \%$ and $5 \%$ BR treated soils instead of the control soils, but avoided the $10 \%$ and $25 \%$ BR concentrations. Besides the common methodology applied in avoidance tests, we offered not only control and treated soil pairs to the animals, but we also paired all the concentrations with each other. E. albidus chose $10 \%$ BR amount in soil instead of $25 \%$ BR in all cases. With the avoidance test we could show not only negative, but also positive effects of soil amendments: BR addition to soils at up to $5 \%$ can result in a better habitat for potworms.
\end{abstract}

\section{Keywords}

potworm, Enchytraeus albidus, bauxite residue, acute toxicity, avoidance

\section{Introduction}

The potworms or enchytraeids are a group of citellate annelids (or microannelids) [1, 2]. Potworms have essential role in the decomposition of organic matter and nutrient cycling [3, 4]. They have an influence on air permeability, pore structure and aggregate stability in soils [5, 6]. Because of their importance in soil ecosystems, enchytraeids have been used for ecotoxicological testing in laboratory to test the effect of pesticides, metals and other chemicals [7]. Their first usage as ecotoxicological test animals was presented in 1968 [8], and nowadays there are several test methods using potworms to measure the effect of different environmental stress-factors on these animals [2]. The avoidance behavior of animals, e.g. Collembola and earthworms, can be used as measurement endpoint in ecotoxicity tests $[9,10]$, because it influences the energy budget of animals by dispending energy on detecting and escaping from hazard [11]. Some studies examined the effect of xenobiotics, e.g. pesticides and metals on the avoidance behavior of potworms [11, 12]. Standardized ecotoxicity tests focus on the measurement of the bioaccumulation of chemicals in potworms [13] and the effect of chemicals on their reproduction and mortality [14].

Bauxite residue (red mud) is the waste of alumina production. Typically, 0.7-2 tonnes of residue per each tonne of alumina is generated [15]. Even though each bauxite residue is different in composition, most of them contain $\mathrm{Fe}_{2} \mathrm{O}_{3}, \mathrm{Al}_{2} \mathrm{O}_{3}, \mathrm{SiO}_{2}, \mathrm{TiO}_{2}, \mathrm{CaO}, \mathrm{Na}_{2} \mathrm{O}$ and LOI (loss on ignition) as main components [16]. This material is highly saline $\left(>50 \mathrm{~g} \mathrm{~L}^{-1}\right)$ and alkaline ( $\mathrm{pH} \mathrm{10-13),} \mathrm{which} \mathrm{rep-}$ resents the main disposal problem in the alumina industry [17]. The high risk of bauxite residue deposition was demonstrated at Ajka (Hungary) [18-20]. As a reuse option the bauxite residue can be applied as a soil amendment [21, 22], or as immobilizer of metals, such as $\mathrm{Cd}, \mathrm{Pb}$ and $\mathrm{Zn}$, in soil [23-25]. However, in the case of such applications the environmental risks should always be assessed, which require new problem-specific ecotoxicological test methods [26]. 
There are only few studies available on the ecotoxicological effects of bauxite residues on soil living animals. The environmental effects of the bauxite residue contaminated soil after the Ajka spill were assessed on-site through the Collembola fauna [27] and by laboratory acute toxicity tests with Collembola (Folsomia candida) $[28,29]$. Maddocks [30] tested the effect of metal-loaded Bauxol reagent produced from bauxite residue on earthworm (Eisenia fetida), while Courtney et al. [31] examined the succession rate of macro-athropodes on recultivated bauxite residue. In this study we investigated for the first time the avoidance behavior of potworms on bauxite residue amended soils. In the standardized method with earthworms and in previous studies with potworms the examined sample was only paired with the control to test avoidance behavior (selection of a preferable area of soil over the area they escape from [2, 12]) [11, 32], but in this study we paired with each other also the soil samples amended with various bauxite residue doses to gain a more detailed picture on potworm behavior in contact with bauxite residue amended soils.

\section{Materials and Methods}

\subsection{Materials}

The bauxite residue $(\mathrm{BR} ; \mathrm{pH}=10.4)$ originated from a storing area in Hungary (Table 1). The acidic sandy soil is from Nyírlugos (NY), the carbonated sandy soil from Örbottyán (OB), and the silty soil from Nagyhörcsök $(\mathrm{NH})$, Hungary (Table 2).

Table 1 Total (aqua regia extractable) and mobile (distilled water extractable) element content of BR

\begin{tabular}{|c|c|c|}
\hline $\begin{array}{l}\text { Element } \\
(\mathrm{mg} / \mathrm{kg})\end{array}$ & $\begin{array}{l}\text { Total content }{ }^{\mathrm{a}} \\
\qquad(\mathrm{mg} / \mathrm{kg})\end{array}$ & $\begin{array}{c}\text { Mobile content }{ }^{\mathrm{b}} \\
(\mathrm{mg} / \mathrm{kg})\end{array}$ \\
\hline $\mathrm{Al}$ & 5011 & 567 \\
\hline As & 28.5 & 0.392 \\
\hline $\mathrm{Co}$ & 39.1 & $<\mathrm{DL}$ \\
\hline $\mathrm{Cr}$ & 256 & 0.148 \\
\hline $\mathrm{Cu}$ & 70.4 & $<\mathrm{DL}$ \\
\hline Mo & ND & 1.97 \\
\hline $\mathrm{Na}$ & 27620 & 1792 \\
\hline $\mathrm{Ni}$ & 165 & $<\mathrm{DL}$ \\
\hline $\mathrm{Zn}$ & 43.2 & $<\mathrm{DL}$ \\
\hline V & 171 & 4.36 \\
\hline \multicolumn{3}{|c|}{$\begin{array}{l}\text { ND: no data, DL: detection limit, } \mathrm{DL}_{\mathrm{Co}}=0.008 \mathrm{mg} / \mathrm{kg}, \\
\mathrm{DL}_{\mathrm{Cu}}=0.050 \mathrm{mg} / \mathrm{kg}, \mathrm{DL}_{\mathrm{Ni}}=0.040 \mathrm{mg} / \mathrm{kg}, \mathrm{DL}_{\mathrm{Zn}}=0.050 \mathrm{mg} / \mathrm{kg} \\
{ }^{\mathrm{a}} \text { Total element content measured after aqua regia digestion [33] } \\
{ }^{\mathrm{b}} \text { Mobile element content measured after distilled water extraction [34] }\end{array}$} \\
\hline
\end{tabular}

Table 2 Soil properties

\begin{tabular}{|c|c|c|c|}
\hline Soil properties & $\mathrm{NH}$ & NY & OB \\
\hline Sand $(\%)(>0.05 \mathrm{~mm})^{\mathrm{a}}$ & 17 & 85 & 81 \\
\hline Silt $(\%)(0.05-0.002 \mathrm{~mm})^{\mathrm{a}}$ & 60 & 10 & 13 \\
\hline Clay $(\%)(<0.002 \mathrm{~mm})^{\mathrm{a}}$ & 23 & 5 & 6 \\
\hline Water holding capacity $(\%)^{\mathrm{b}}$ & 36 & 30 & 32 \\
\hline Humus $(\%)^{c}$ & 3.1 & 0.5 & 1.0 \\
\hline $\mathrm{CaCO}_{3}(\%)^{\mathrm{d}}$ & 1.8 & 0.0 & 3.3 \\
\hline $\mathrm{pH}\left(\mathrm{H}_{2} \mathrm{O}\right)^{\mathrm{e}}$ & 7.6 & 4.9 & 7.7 \\
\hline
\end{tabular}

\subsection{Experimental set up}

We mixed BR with the soils at $1 \mathrm{w} / \mathrm{w} \%, 5 \mathrm{w} / \mathrm{w} \%, 10 \mathrm{w} /{ }_{\mathrm{w}} \%$, $25{ }_{\mathrm{w}}^{\mathrm{w}} \%$ and $50 \mathrm{w} / \mathrm{w} \%$ (BR 1-50\%) and an untreated soil was used as control (C). Ujaczki et al. [22, 29] suggested to apply BR in sandy soils at up to $5 \%$, therefore smaller and higher amounts were tested. The soil was watered to $60 \%$ water holding capacity and kept at $22 \pm 2{ }^{\circ} \mathrm{C}$ for a week before testing.

\subsection{Chemical analysis}

The $\mathrm{pH}$ was measured in 1:2,5 soil: distilled water suspension after $30 \mathrm{~min}$ shaking at $160 \mathrm{rpm}$ in three replicates [35]. Total element content was measured by NITON XL3t 600 in three replicates.

\subsection{Sample preparation}

The soils were air dried, ground and sieved through a $1 \mathrm{~mm}$ sieve before testing. Beyond testing direct effect of whole soils (WS), we made soil suspensions (S) and soil extracts (E) [37]. Shortly, $4.5 \mathrm{~g}$ of soil was put into an Erlenmeyer flask with $45 \mathrm{ml}$ of distilled water (1:10 solid: liquid ratio) shaken for 4 hours at $140 \mathrm{rpm}$ to make the soil suspension. Then the suspension was settled for five minutes and filtered through 4-12 $\mu \mathrm{m}$ hole-diameter filter paper to make the soil extract. The samples were stored at $5{ }^{\circ} \mathrm{C}$ until testing.

\subsection{Test organisms}

The samples were tested by potworm acute mortality and avoidance tests. The population of Enchytraeus albidus (Henle 1837) was from our own stock culture. We maintained the stock culture in potting soil at constant temperature $\left(24 \pm 1{ }^{\circ} \mathrm{C}\right)$ with twice a week wetting, protected from direct light. The animals were fed with ground cereal once a week. Adult, minimum $12 \mathrm{~mm}$ long animals were applied for testing. 


\subsection{Acute mortality tests}

The acute mortality tests were carried out according to OECD 207 [39] modified for enchytraeids in five replicates. For the whole soil test, we measured $25 \mathrm{~g}$ of soil in a $9 \mathrm{~cm}$ glass Petri-dish wetted with $5 \mathrm{ml}$ of boiled tap water, for the soil suspension and soil extract we added $3 \mathrm{ml}$ of the liquid on a filter paper in similar Petri-dishes. We added 5 adult animals to each sample and kept them in the dark at $21 \pm 1{ }^{\circ} \mathrm{C}$ for $96 \mathrm{~h}$. The number of living animals was counted.

\subsection{Avoidance tests}

The avoidance tests were carried out based on Amorim et al.'s work [40], but we modified and complemented their method. Avoidance is an active selection activity of the animals between two samples with different properties $[2,12]$. Instead of making pairs only between the control (C) and the treated soils (BR1-25\%), we offered the animals all the concentrations in pairs. We paired: C-C; C-BR1 \%; C-BR5 \%; C-BR10 \%; C-BR25 \%; BR1-BR5 \%; BR1-BR10 \%; BR1-BR25 \%; BR5-BR10\%; BR5-BR25 \%; BR10-BR25\%. We also paired the same $\mathrm{BR}$ concentrations in the various soil types with each other (NH-NY, NH-OB, NY-OB).

We introduced 20-20 g of soil onto the two sides of Petri-dishes, wetted them with 4-4 $\mathrm{ml}$ of boiled tap water. The tests were carried out in six replicates with fourfour adult animals placed on each side of the Petri-dish. After 96 hours we counted the animals on the two sides of each Petri-dish.

\subsection{Statistical analysis}

We applied Pearson correlation analysis to examine correlations between BR amount (as numerical variables), and $\mathrm{pH}$, element content, number of dead animals in the acute toxicity tests and number of animals at the two sides of Petri-dishes in avoidance test. We used One-way ANOVA (Fisher LSD) to determine the statistically significant differences between the means of the number of dead animals, $\mathrm{pH}$ and element content in each treatment. We applied one-way ANOVA (Type 1 LR test) in Poisson-distribution to compare the average number of animals at the two sides of Petri-dishes in avoidance test in case of different pairs. We applied one-way and multi-way ANOVA for the normalized data in StatSoft ${ }^{\circledR}$ Statistica 7.0 programs to investigate which factorial variables had significant effect on the number of animals at the two sides of Petri-dishes in avoidance tests. We applied $95 \%$ confidence intervals for significant differences. The Figures were produced by
Microsoft Office Excel 2013 and Allplan 2014 softwares. In the tables and diagrams the letters represent the significantly different groups in the one-way ANOVA tests. The " $r$ " value in the tables represents the correlation coefficient. Correlation was considered very strong when r-value $>|\mathbf{0 . 8 5}|$ and strong when r-value $>|0.60|$ [41]. The concentration-response curves were generated with Origin 6.0 to determine $\mathrm{LC}_{\mathrm{x}}$ (lethal concentration) values. Avoidance \% was calculated as follows: $\mathrm{A}=$ (animal number in control / lower BR concentration / first soil) - (animal number in treated soil / higher BR concentration / second soil)/total number of animals * 100. The chosen $\%$ was calculated as follows: $\mathrm{C}=$ (number of animals at one side of the Petri-dish) $/ 8 * 100$. The habitat function of soils is considered to be limited if on average $\geq 75 \%$ of worms (chosen $\% \geq 75 \%$, avoidance $\% \geq 50 \%$ ) (based on the Poisson-distribution) were found in the control or the treated soil [40].

\section{Results and discussions}

\section{$3.1 \mathrm{pH}$ and element content of BR treated soils}

$\mathrm{BR}$ addition raised significantly the $\mathrm{pH}$ of the whole soils, soil suspensions and extracts starting from $1 \%$ BR amount (except for NH-E, OB-WS and OB-E) (Table 3).

The $\mathrm{pH}$ exceeded the threshold value of $9[42,43]$ starting from $10 \%$ BR amount in NH-WS, NH-S, NY-WS and NY-S, and from $5 \%$ BR amount in OB-WS and OB-S.

Table $3 \mathrm{pH}$ in BR treated soils (WS), suspensions (S) and extracts (E), bold: $\mathrm{pH}>9$. Correlation coefficient $(\mathrm{r})$ between $\mathrm{pH}$ and $\mathrm{BR}$ amount in soil, bold $r>|0.85|$

\begin{tabular}{|c|c|c|c|c|c|c|c|}
\hline Soil type & $\mathrm{C}$ & $1 \%$ & $5 \%$ & $10 \%$ & $25 \%$ & $50 \%$ & $\mathrm{r}$ \\
\hline NH - WS & $\begin{array}{c}8.0 \pm \\
0.0^{\mathrm{a}}\end{array}$ & $\begin{array}{c}8.1 \pm \\
0.0^{\mathrm{b}}\end{array}$ & $\begin{array}{c}8.6 \pm \\
0.0^{\mathrm{c}}\end{array}$ & $\begin{array}{c}9.1 \pm \\
0.0^{d}\end{array}$ & $\begin{array}{c}9.5 \pm \\
0.1^{\mathrm{e}}\end{array}$ & $\begin{array}{c}10.3 \\
\pm 0.6^{\mathrm{f}}\end{array}$ & 0.90 \\
\hline $\mathrm{NH}-\mathrm{S}$ & $\begin{array}{c}8.0 \pm \\
0.1^{\mathrm{a}}\end{array}$ & $\begin{array}{c}8.3 \pm \\
0.0^{\mathrm{b}}\end{array}$ & $\begin{array}{c}8.7 \pm \\
0.0^{\mathrm{c}}\end{array}$ & $\begin{array}{c}9.1 \pm \\
0.0^{d}\end{array}$ & $\begin{array}{c}9.8 \pm \\
0.0^{\mathrm{e}}\end{array}$ & $\begin{array}{c}10.3 \\
\pm 0.0^{f}\end{array}$ & 0.99 \\
\hline NH - E & $\begin{array}{c}7.7 \pm \\
0.1^{\mathrm{a}}\end{array}$ & $\begin{array}{c}7.8 \pm \\
0.0^{\mathrm{a}}\end{array}$ & $\begin{array}{c}8.0 \pm \\
0.0^{\mathrm{a}}\end{array}$ & $\begin{array}{c}8.3 \pm \\
0.1^{\mathrm{b}}\end{array}$ & $\begin{array}{c}8.8^{ \pm} \\
0.2^{\mathrm{c}}\end{array}$ & $\begin{array}{c}9.6 \pm \\
0.1^{d}\end{array}$ & 0.99 \\
\hline NY - WS & $\begin{array}{c}5.0 \pm \\
0.2^{\mathrm{a}}\end{array}$ & $\begin{array}{c}8.5 \pm \\
0.0^{\mathrm{b}}\end{array}$ & $\begin{array}{c}8.8 \pm \\
0.1^{\mathrm{b}}\end{array}$ & $\begin{array}{c}9.4 \pm \\
0.2^{\mathrm{c}}\end{array}$ & $\begin{array}{c}9.8 \pm \\
0.0^{d}\end{array}$ & $\begin{array}{c}9.7 \pm \\
0.0^{d}\end{array}$ & 0.97 \\
\hline$N Y-S$ & $\begin{array}{c}5.2 \pm \\
0.0^{\mathrm{a}}\end{array}$ & $\begin{array}{c}8.4 \pm \\
0.1^{\mathrm{b}}\end{array}$ & $\begin{array}{c}9.0 \pm \\
0.1^{\mathrm{c}}\end{array}$ & $\begin{array}{c}9.5 \pm \\
0.1^{\mathrm{d}}\end{array}$ & $\begin{array}{c}10.0 \pm \\
0.0^{\mathrm{e}}\end{array}$ & $\begin{array}{c}9.8 \pm \\
0.0^{f}\end{array}$ & 0.99 \\
\hline NY - E & $\begin{array}{c}6.5 \pm \\
0.3^{\mathrm{a}}\end{array}$ & $\begin{array}{c}7.3 \pm \\
0.0^{\mathrm{b}}\end{array}$ & $\begin{array}{c}7.2 \pm \\
0.1^{\mathrm{b}}\end{array}$ & $\begin{array}{c}7.6 \pm \\
0.1^{\mathrm{b}}\end{array}$ & $\begin{array}{c}9.0 \pm \\
0.6^{\mathrm{c}}\end{array}$ & $\begin{array}{c}9.3 \pm \\
0.3^{\mathrm{c}}\end{array}$ & 0.93 \\
\hline OB - WS & $\begin{array}{c}8.5 \pm \\
0.1^{\mathrm{a}}\end{array}$ & $\begin{array}{c}8.6 \pm \\
0.0^{\mathrm{a}}\end{array}$ & $\begin{array}{c}9.1 \pm \\
0.0^{b}\end{array}$ & $\begin{array}{c}9.4 \pm \\
0.0^{\mathrm{c}}\end{array}$ & $\begin{array}{c}9.8 \pm \\
0.1^{\mathrm{d}}\end{array}$ & $\begin{array}{c}10.0 \pm \\
0.0^{\mathrm{d}}\end{array}$ & 0.97 \\
\hline $\mathrm{OB}-\mathrm{S}$ & $\begin{array}{c}8.8 \pm \\
0.1^{\mathrm{a}}\end{array}$ & $\begin{array}{c}9.0 \pm \\
0.0^{\mathrm{b}}\end{array}$ & $\begin{array}{c}9.5 \pm \\
0.0^{\mathrm{c}}\end{array}$ & $\begin{array}{c}10.0 \pm \\
0.0^{d}\end{array}$ & $\begin{array}{c}10.2 \pm \\
0.0^{\mathrm{e}}\end{array}$ & $\begin{array}{c}10.3 \\
\pm 0.0^{\mathrm{e}}\end{array}$ & 0.99 \\
\hline$O B-E$ & $\begin{array}{c}7.0 \pm \\
0.4^{\mathrm{a}}\end{array}$ & $\begin{array}{c}7.3 \pm \\
0.1^{\mathrm{a}}\end{array}$ & $\begin{array}{c}7.8 \pm \\
0.1^{\mathrm{b}}\end{array}$ & $\begin{array}{c}7.7 \pm \\
0.2^{b}\end{array}$ & $\begin{array}{c}8.8 \pm \\
0.1^{\mathrm{c}}\end{array}$ & $\begin{array}{c}9.2 \pm \\
0.2^{\mathrm{c}}\end{array}$ & 0.99 \\
\hline
\end{tabular}


In $\mathrm{E}$ the $\mathrm{pH} 9$ was exceeded only upon $50 \%$ BR addition to all soils. There was a linear correlation between BR concentration and the $\mathrm{pH}$. BR addition increased the soil $\mathrm{pH}$ as proved by literature data $[21,22,44]$ due to its high $\mathrm{NaOH}$ content $[16,17]$.

The total As content exceeded the Hungarian Limit Value at $10 \% \mathrm{BR}$ in soils [43] and V surpassed the risk based Dutch Intervention Value at $50 \%$ BR [45] (Table 4). For $\mathrm{Cr}$ the Hungarian Limit Value was reached at $5 \% \mathrm{BR}$ in $\mathrm{NH}, 10 \% \mathrm{BR}$ in $\mathrm{OB}$ and $25 \% \mathrm{BR}$ in NY. BR usually contains these elements at a high concentration [46-52].

\subsection{Acute mortality tests}

The direct contact with whole soils had significant lethal effect on E. albidus, while soil suspensions and soil extracts did not cause significant lethality at up to $50 \%$ BR in the soils (Fig. 1).

Table 4 As, Cr and V content of BR treated soils (WS). Bold: amount $>$ Limit Value (As, Cr: [43]; V: [45]); < DL: below Detection Limit; Correlation coefficient (r) between element content and BR amount in soil, bold $r>|0.85|$

\begin{tabular}{|c|c|c|c|}
\hline Element & As (mg/kg) & $\mathrm{Cr}(\mathrm{mg} / \mathrm{kg})$ & $\mathrm{V}(\mathrm{mg} / \mathrm{kg})$ \\
\hline Limit & 15 & 75 & 250 \\
\hline Soil & & $\mathrm{NH}$ & \\
\hline $\mathrm{C}$ & $10.95+0.24^{\mathrm{a}}$ & $35.23+7.86^{\mathrm{a}}$ & $40.96+2.19^{\mathrm{a}}$ \\
\hline $1 \%$ & $11.74+0.58^{\mathrm{a}}$ & $39.17+11.03^{\mathrm{a}}$ & $65.28+3.66^{\mathrm{a}}$ \\
\hline $5 \%$ & $18.50+1.40^{b}$ & $80.99+16.39^{b}$ & $98.46+8.48^{\mathrm{b}}$ \\
\hline $10 \%$ & $23.07+1.63^{b}$ & $79.88+9.39^{b}$ & $115.03+6.89^{b}$ \\
\hline $25 \%$ & $40.73+2.43^{c}$ & $116.73+15.50^{\mathrm{c}}$ & $189.38+5.82^{\mathrm{c}}$ \\
\hline $50 \%$ & $69.52+8.01^{d}$ & $176.21+6.04^{d}$ & $342.11+31.06^{c}$ \\
\hline $\mathrm{r}$ & 0.98 & 0.93 & 0.99 \\
\hline Soil & & NY & \\
\hline $\mathrm{C}$ & $<\mathrm{DL}^{\mathrm{a}}$ & $19.46+12.16^{\mathrm{a}}$ & $<\mathrm{DL}^{\mathrm{a}}$ \\
\hline $1 \%$ & $4.59+0.48^{\mathrm{a}}$ & $15.09+0.00^{\mathrm{a}}$ & $38.16+3.62^{\mathrm{a}}$ \\
\hline $5 \%$ & $9.45+1.55^{\mathrm{a}}$ & $27.35+11.42^{\mathrm{a}}$ & $66.02+9.60^{b}$ \\
\hline $10 \%$ & $15.74+3.02^{b}$ & $63.35+0.98^{b}$ & $116.87+8.74^{c}$ \\
\hline $25 \%$ & $33.02+3.16^{c}$ & $107.37+16.42^{\mathrm{c}}$ & $213.18+21.48^{\mathrm{d}}$ \\
\hline $50 \%$ & $61.03+3.38^{d}$ & $241.39+16.11^{d}$ & $353.40+3.00^{e}$ \\
\hline $\mathrm{r}$ & 0.99 & 0.97 & 0.99 \\
\hline Soil & & $\mathrm{OB}$ & \\
\hline $\mathrm{C}$ & $4.8+0.00^{\mathrm{a}}$ & $<\mathrm{DL}^{\mathrm{a}}$ & $33.19+0.00^{\mathrm{a}}$ \\
\hline $1 \%$ & $5.96+0.74^{\mathrm{a}}$ & $4.89+8.46^{\mathrm{a}}$ & $41.22+8.70^{\mathrm{a}}$ \\
\hline $5 \%$ & $9.13+1.62^{\mathrm{a}}$ & $37.69+8.66^{\mathrm{a}}$ & $74.70+7.24^{\mathrm{a}}$ \\
\hline $10 \%$ & $19.27+3.86^{b}$ & $79.25+25.54^{b}$ & $141.77+20.35^{b}$ \\
\hline $25 \%$ & $30.10+0.87^{c}$ & $101.11+9.44^{c}$ & $198.94+11.14^{\mathrm{c}}$ \\
\hline $50 \%$ & $59.56+3.55^{d}$ & $199.28+24.35^{d}$ & $343.46+53.51^{d}$ \\
\hline $\mathrm{r}$ & 0.98 & 0.97 & 0.98 \\
\hline
\end{tabular}

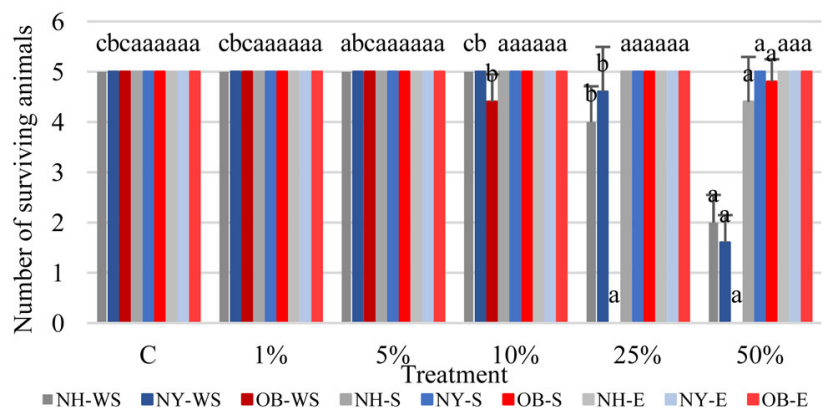

Fig. 1 E. albidus lethality in BR treated whole soils (WS), soil suspensions (S) and soil extracts (E)

The effect of soil type, the sample preparation mode, the BR amount and their interaction influenced statistically significantly the amount of surviving animals. Testing of the whole soil samples instead of extracts is a more sensitive method to measure the toxic effect of BRs on the survival of potworms. This result is supported by previous findings on Direct Toxicity Assessment (DTA), which is of high environmental relevance because it represents all possible interactions between contaminants, ecosystem members and the matrix [53].

According to Sydow et al. [54], in case of testing the toxic effect of metals one should pay more attention not only to the exposition mode (e.g. exposition to free ions), but also to the chosen test soil. The sensitivity of invertebrates was different in artificial OECD and natural soils (e.g. $\mathrm{EC}_{50}$ : 3.78-5150 $\mathrm{mg} \mathrm{Zn/kg}$ in OECD soil and 35.00$7264 \mathrm{mg} \mathrm{Zn} / \mathrm{kg}$ natural soil) due to the relatively small variability of pore water concentrations of dissolved base cations in OECD soils.

Kuperman et al. [55] also found that the soil physical and chemical properties (e.g. pH, organic matter content or soil particle size) affect the toxicity of pesticides to three species of the genus Enchytraeus, including E. albidus. Instead of using artificial soils, they suggested to conduct toxicity testing on natural soil types which have properties supporting higher bioavailability of test chemicals.

We found strong significant linear correlation between the number of dead E. albidus individuals, BR concentration, $\mathrm{pH}$, total $\mathrm{As}, \mathrm{Cr}$ and $\mathrm{V}$ concentrations in case of the whole soil testing option (Table 5). The $\mathrm{pH}$ of WS was always higher than the $\mathrm{pH}$ tolerance of E. albidus (4.87.4 [56]) starting with $1 \%$ BR treatment.

The $\mathrm{LC}_{20}$ and $\mathrm{LC}_{50}$ were different in the three soils (Table 6). BR in OB was the most toxic for E. albidus with $\mathrm{LC}_{20}$ of $9 \% \mathrm{BR}$ and $\mathrm{LC}_{50}$ of $11 \% \mathrm{BR}$, while $\mathrm{NY}$ and $\mathrm{NH}$ resulted in similar LC values. The animals could tolerate 
Table 5 Correlation coefficient (r-value) between the number of dead $E$. albidus individuals in each soil type and sample preparation mode, BR concentration, $\mathrm{pH}$, total As, $\mathrm{Cr}$ and $\mathrm{V}$. Italics $\mathrm{r}>|0.60|$. ND: no data

NH- NH- NH- NY- NY- NY- OB- OB- OB-

WS $S$ E WS $S$ E WS $S$ E

\begin{tabular}{llllllllll}
\multicolumn{1}{c}{$\mathbf{r}$} \\
\hline $\mathrm{BR}$ & 0.80 & 0.39 & 0.00 & 0.69 & 0.00 & 0.00 & 0.80 & 0.39 & 0.00 \\
$\mathrm{pH}$ & 0.74 & 0.35 & 0.00 & 0.55 & 0.00 & 0.00 & 0.74 & 0.39 & 0.00 \\
$\mathrm{As}$ & 0.74 & $\mathrm{ND}$ & $\mathrm{ND}$ & 0.66 & $\mathrm{ND}$ & $\mathrm{ND}$ & 0.84 & $\mathrm{ND}$ & $\mathrm{ND}$ \\
$\mathrm{Cr}$ & 0.78 & $\mathrm{ND}$ & $\mathrm{ND}$ & 0.68 & $\mathrm{ND}$ & $\mathrm{ND}$ & 0.76 & $\mathrm{ND}$ & $\mathrm{ND}$ \\
$\mathrm{V}$ & 0.79 & $\mathrm{ND}$ & $\mathrm{ND}$ & 0.66 & $\mathrm{ND}$ & $\mathrm{ND}$ & 0.79 & $\mathrm{ND}$ & $\mathrm{ND}$ \\
\hline
\end{tabular}

Table $6 \mathrm{LC}_{20}$ and $\mathrm{LC}_{50}$ values in the whole soil samples

\begin{tabular}{lccc}
\hline & NH-WS & NY-WS & OB-WS \\
\hline $\mathrm{LC}_{20}[\% \mathrm{BR}]$ & 27.6 & 33.6 & 8.9 \\
$\mathrm{LC}_{50}[\% \mathrm{BR}]$ & 41.9 & 44.2 & 10.7 \\
\hline
\end{tabular}

the highest $\mathrm{BR}$ addition $\left(\mathrm{LC}_{20}=33 \% \mathrm{BR}\right)$ in the acidic sandy NY soil, and the population was the most sensitive for BR in the carbonated sandy OB soil.

The literature contains limited number of studies in which the authors examined the effect of this BR on animals. Ujaczki et al. [29] did not detect significant mortality in case of Folsomia candida (Collembola), at up to $40 \%$ BR in a sandy soil $(\mathrm{pH}=7.5)$ from the Ajka region in Hungary 1 month after treatment, and at up to $30 \%$ after the $2^{\text {nd }}$ and $8^{\text {th }}$ months of treatment. Based on the complex evaluation of metalloid content, $\mathrm{pH}$ and the test results with testorganisms from three trophic levels the authors concluded, that up to $5 \%$ BR can be mixed into the Ajka soil without any mid-term adverse effects on the soil as natural habitat.

In another experiment with the NY soil similar recommendation was given by Ujaczki et al. [22]. In addition, $10 \% \mathrm{BR}$ dose in NY, 10 months after BR treatment, resulted in $20 \%$ inhibition for the protozoon Tetrahymena pyriformis. Rékási et al. [28] reported mortality of $F$. candida in a $10 \mathrm{~cm}$ BR layer covered soil column (soil from Ajka region) also in the deeper soil layers $(30-50 \mathrm{~cm})$, but the highest mortality was $13 \%$.

Some studies examined the individual effect of metals on potworms. Lock and Janssen [57] suggested that terrestrial ecotoxicity data of metals, such as $\mathrm{Cd}$ and $\mathrm{Zn}$ to E. albi$d u s$, should rather be correlated with the soil $\mathrm{pH}$ and cation exchange capacity than clay and organic matter content. They measured $14 \mathrm{~d} \mathrm{LC}_{50}$ between $83.0-1140 \mathrm{mg} \mathrm{Zn/kg} \mathrm{dry}$ soil and 55.2-704 $\mathrm{mg} \mathrm{Cd} / \mathrm{kg}$ dry soil in various soil types. The toxic effect of $\mathrm{Cd}$ and $\mathrm{Zn}$ may be due to disturbance in the cellular redox status of E. albidus. $\mathrm{Cd}$ and $\mathrm{Zn}$ induced significant changes in the antioxidant enzyme activities and substrate levels as well as increased lipid peroxidation, indicating oxidative damage [58]. The form of metal added into the artificial soil has also influenced the results of acute and chronic toxicity tests. E.g. the acute toxicity of $\mathrm{ZnCl}_{2}$ was higher for E. albidus than of $\mathrm{Zn}$ powder and $\mathrm{ZnO}$, while chronic toxicity was similar [59].

For copper, in case of the acute toxicity tests (21 days) the $\mathrm{LC}_{50}$ values were higher than $320 \mathrm{mg} \mathrm{CuCl}{ }_{2} \cdot 2 \mathrm{H}_{2} \mathrm{O} / \mathrm{kg}$ dry weight in the three different soil types. However, the juveniles were more sensitive with an $\mathrm{LC}_{50}$ value from 97 to $>320 \mathrm{mg} \mathrm{CuCl}{ }_{2} \cdot 2 \mathrm{H}_{2} \mathrm{O} / \mathrm{kg}$ dry weight [60]. In case of $\mathrm{Zn}, \mathrm{Cd}, \mathrm{Cu}$ and $\mathrm{Pb}$ in a 21 days acute toxicity test the $\mathrm{LC}_{50}$ was $610 \mathrm{mg} \mathrm{Zn/kg} \mathrm{dry} \mathrm{weight,} 554 \mathrm{mg} \mathrm{Cd} / \mathrm{kg}$ dry weight, $671 \mathrm{mg} \mathrm{Cu} / \mathrm{kg}$ dry weight; $4530 \mathrm{mg} \mathrm{Pb} / \mathrm{kg}$ dry weight in OECD soils, respectively [58].

However, the $\mathrm{EC}_{50}$ values in the reproduction test (42 days) were $211 \mathrm{mg} \mathrm{Zn} / \mathrm{kg}$ dry soil, $58 \mathrm{mg} \mathrm{Cd} / \mathrm{kg}$ dry soil, $337 \mathrm{mg} \mathrm{Cu} / \mathrm{kg}$ dry soil, $394 \mathrm{mg} \mathrm{Pb} / \mathrm{kg}$ dry soil, respectively [61]. $\mathrm{EC}_{50}$ values in reproduction tests with $E$. albidus were $\mathrm{EC}_{50}=637 \mathrm{mg} \mathrm{Cr} / \mathrm{kg}$ dry soil for chromium (III) [62], and for nickel in OECD soil $\mathrm{EC}_{50}$ was $275 \mathrm{mg}$ $\mathrm{Ni} / \mathrm{kg}$ dry soil, while the $21 \mathrm{~d} \mathrm{LC}_{50}$ was $510 \mathrm{mg} / \mathrm{kg}$ dry soil, respectively [63].

$\mathrm{Cu}$ and $\mathrm{Ni}$ have similar toxicity mechanisms in E. albidus which are mainly related to oxidative stress and response to ROS. Additionally, $\mathrm{Ni}$ affects immune response pathways [64].

\subsection{Avoidance tests}

As a pre-screening test we tested the avoidance behavior of $E$. albidus in control vs. control in case of the three different soils (Table 7). The results proved that the potworms do not make a choice between the two sides of the Petri-dish containing the same soils.

E. albidus significantly preferred $1 \% \mathrm{BR}$ treated NY soil compared to the control (Fig. 2; Table 8). The $5 \%$

Table 7 Control-Control avoidance of E. albidus in case of different soils

\begin{tabular}{lcccccc}
\hline & \multicolumn{2}{c}{$\mathrm{NH}-\mathrm{C}$} & \multicolumn{2}{c}{$\mathrm{NY}-\mathrm{C}$} & \multicolumn{2}{c}{ OB - C } \\
& side 1 & side 2 & side 1 & side 2 & side 1 & side 2 \\
\hline & 4 & 4 & 5 & 3 & 4 & 4 \\
& 5 & 3 & 3 & 5 & 4 & 4 \\
& 3 & 5 & 4 & 4 & 4 & 4 \\
Av. number & $\mathbf{4 . 0 0}$ & $\mathbf{4 . 0 0}$ & $\mathbf{4 . 0 0}$ & $\mathbf{4 . 0 0}$ & $\mathbf{4 . 0 0}$ & $\mathbf{4 . 0 0}$ \\
St. deviation & 1.00 & 1.00 & 1.00 & 1.00 & 0.00 & 0.00 \\
Avoidance \% & \multicolumn{2}{c}{0.00} & \multicolumn{3}{c}{0.00} & \multicolumn{2}{c}{0.00} \\
\hline
\end{tabular}


Table 8 The average number of animals at each side of the Petri-dish and avoidance \% (compared to the control or the lower BR concentration). Bold: avoidance $\% \geq 50 \%$.

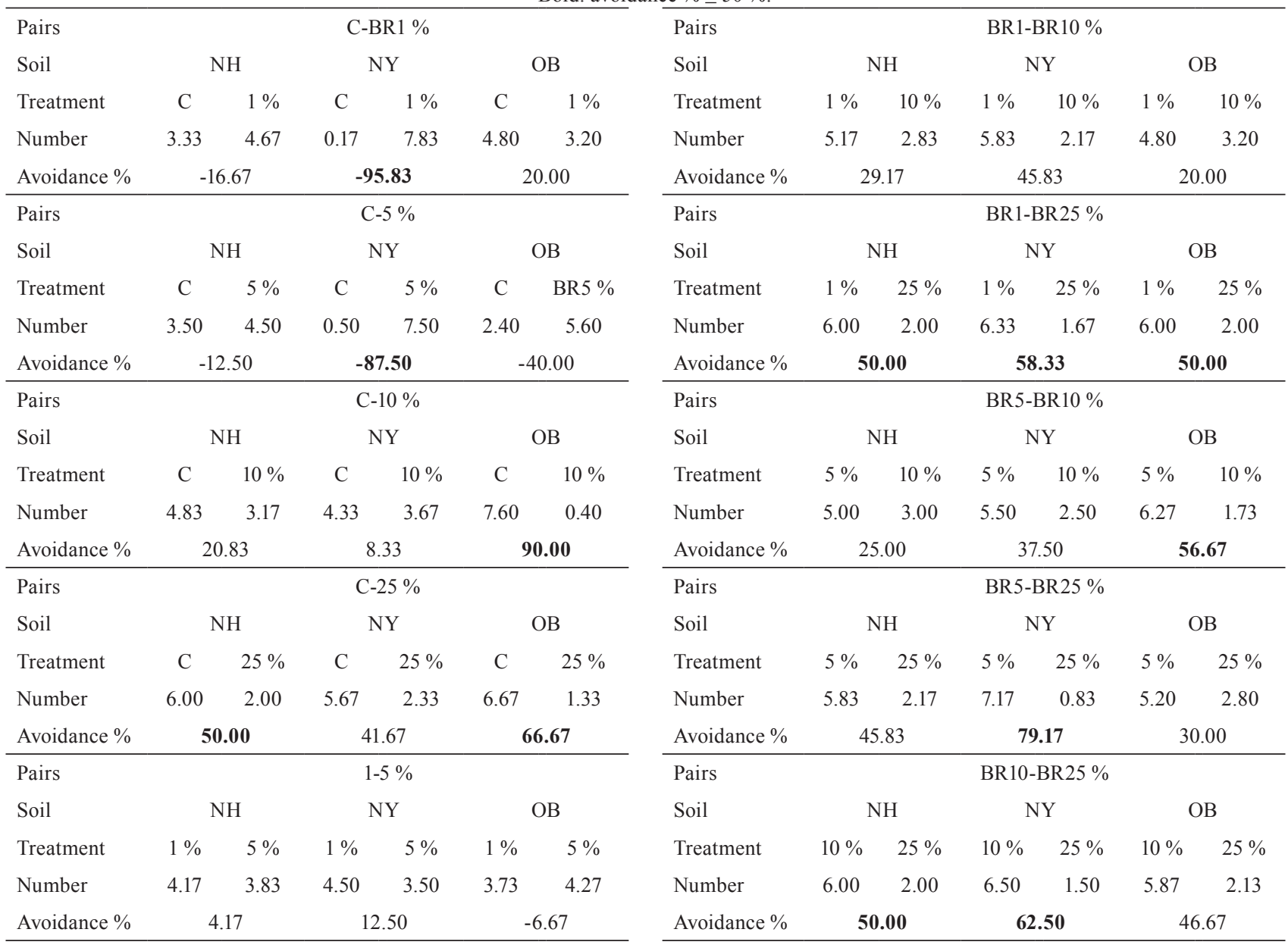

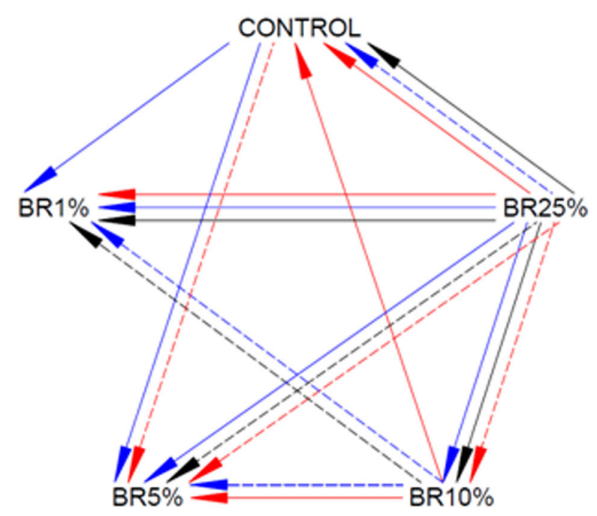

Fig. 2 Choice of E. albidus in BR amended soils.

(Black: NH; blue NY; red OB; continuous line: significant $(\mathrm{p}<0.05)$ and $\geq 75 \%$ chosen $\%$; interrupted line: significant $(p<0.05))$

BR concentration was preferred by potworms in case of NY and OB compared to the control. The animals did not make a choice between $1 \%$ and $5 \%$ BR in soils.

Instead of $10 \% \mathrm{BR}$, animals chose $\mathrm{C}(\mathrm{OB}), 1 \% \mathrm{BR}$ (NY) and $5 \%$ BR (NY, OB) in the soil. $25 \%$ BR amount was avoided in all soils when compared to the control and the lower BR concentrations. The results show that animals could make a difference between the $10 \%$ and $25 \%$ BR concentration: although both were avoided compared to control, they chose always the lower BR amount in this case. The effect of soil type was not significant for the amount of animals at the two sides of the Petri-dish, but the different pairs and the BR concentration in the soil had a significant effect.

The animals chose the NH soil against NY and OB with $\geq 75 \%$ preference (Fig. 3). OB was selected by animals when paired with NY (except for $1 \%$ and $25 \%$ BR in soil). The effect of soil type and soil pairs was significant for the number of animals at the two sides of the Petri-dish.

The avoidance (or area selection) tests were more sensitive than acute toxicity tests to assess soil, as habitat for potworms (or other terrestrial biota), because in this test the animals reacted to lower concentrations of the tested material (BR) than in the mortality test. Avoidance behavior is an ecologically relevant endpoint, which is 


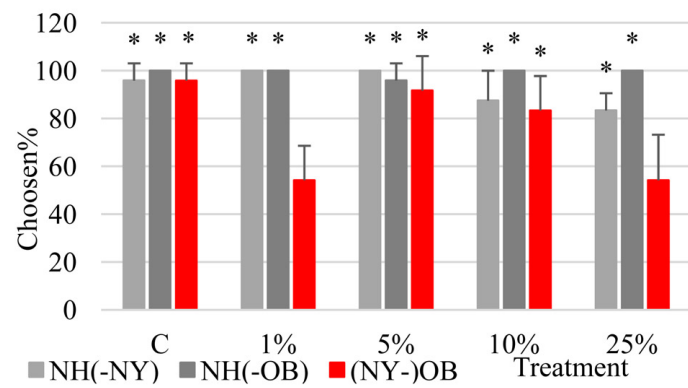

Fig. 3 Choice of E. albidus in various soil types containing different BR concentrations. The columns represent the chosen $\%$ of the soil type compared to the soil type in brackets. Starred: significant $(\mathrm{p}<0.05)$ and $\geq 75 \%$ chosen $\%$

well-useable in soil ecotoxicology tests with Annelids $[40,65,66]$. When the behavior or tolerance of potworms was examined, it was typical that the sublethal end-points (bioaccumulation, reproduction avoidance) were more sensitive compared to lethality [12, 40, 67].

Although the classic avoidance tests, pairing treated samples with the control, are able to forecast the effect of contaminants on potworms, the experimental matrix applied in our study comparing treated samples with each other could provide more detailed information on the behavior of potworms, enabling assessment of the real effects of different soil amendments.

In a metal polluted soil from a mining area E. crypticus adult survival was not affected in general by the soil pollution level, but Enchytraeid reproduction was negatively affected, and this was more pronounced over generations [68]. Avoidance behavior can be similarly sensitive to reproduction in the case of testing waste materials. E.g. in case of incineration ash (INC) $\mathrm{EC}_{50}$ for reproduction was $16.1 \%$ in control soil and $13.7 \%$ for avoidance. Similarly, $\mathrm{EC}_{50}$ for reproduction was $4.1 \%$ in case of contaminated wood chips (WOO) in control soil and $2.9 \%$ for avoidance. E. albidus was more sensitive to INC in avoidance tests $\left(\mathrm{EC}_{50}=4.4 \% \mathrm{INC}\right.$ in control) than E. fetida $\left(\mathrm{EC}_{50}<12.5 \%\right)$ and E. crypticus $\left(\mathrm{EC}_{50}=14.3 \%\right)$, but less sensitive to $\mathrm{WOO}$ (E. albidus: $\mathrm{EC}_{50}=9.6 \% \mathrm{WOO}$ in control, E. fetida $\mathrm{EC}_{50}<4.5 \%$, E. crypticus $\mathrm{EC}_{50}=9.2 \%$ ) [69].

In other experiments, the authors focused on the effect of different metals on avoidance of potworms. An avoidance reaction of E. albidus of less than $80 \%$ was detected in case of $\mathrm{Zn}$ and $\mathrm{Cd}$ at up to $180 \mathrm{mg} / \mathrm{kg}$ dry LUFA 2.2 soil and $560 \mathrm{mg} / \mathrm{kg}$ dry soil, respectively, but $>80 \%$ avoidance was measured for $\mathrm{Cu}$ at $\geq 320 \mathrm{mg} / \mathrm{kg}$ dry soil. The $\mathrm{EC}_{50}$ for avoidance was lower for $\mathrm{Zn}\left(\mathrm{EC}_{50}=92 \mathrm{ppm}\right)$, $\mathrm{Cd}\left(\mathrm{EC}_{50}=362 \mathrm{ppm}\right)$ and $\mathrm{Cu}\left(\mathrm{EC}_{50}=133 \mathrm{ppm}\right)$ compared to $\mathrm{LC}_{50}$ from literature. When compared with reproduction $\mathrm{EC}_{50}$ values, the difference in sensitivity depended on the type of metal [40]. $\mathrm{AC}_{50}$ (the concentration inducing an avoidance of $50 \%$ ) for E. albidus was $571 \mathrm{mg} / \mathrm{kg}$ dry soil for $\mathrm{Cd}$ and $215 \mathrm{mg} / \mathrm{kg}$ dry soil for $\mathrm{Zn}$ in LUFA 2.2 soil upon simultaneous occurrence of $\mathrm{Zn}$ and $\mathrm{Cd}$ in the soil. These $\mathrm{AC}_{50}$ values were higher compared to when these metals occurred individually in the soil [11]. These findings underline the importance of direct toxicity testing of waste materials, which are always the mixture of chemicals.

\section{Conclusions}

Based on our results $\leq 5 \%$ BR concentration does not have any presumable negative effect on the Enchytraeus albidus decomposer soil biota. This finding is in accordance with previous studies of Ujaczki et al. [22, 29]. $\mathrm{LC}_{20}$ values from the acute toxicity tests indicated, that BR addition is acceptable for potworms at $9 \%$ in the carbonated sandy soil, at $28 \%$ in the silty soil, and at $34 \%$ in the acidic sandy soil. Direct contact testing of whole soil samples was a more sensitive method, than testing of the soil suspension or soil extract, which indicated no significant mortality up to $50 \%$ BR in soils. This suggests that testing whole soil samples is a better choice for the assessment of the real environmental risks.

Furthermore, the avoidance test results proved to be more sensitive to test the effect of BR on potworms. The acute toxicity (mortality) tests showed that 1-5\% BR treated soils may result in a better habitat for enchytraeids, than the untreated control soil, as potworms chose the BR treated soils over the control. The avoidance tests enabled the assessment of both the negative and positive effects of this soil amendment.

In case of other test organisms there was no significant difference between the acute toxic effect of $10 \%$ and $25 \%$ BR in the acidic sandy soil, but the avoidance test showed clearly that E. albidus chose $10 \%$ BR instead of $25 \%$ BR when these concentrations were paired with each other. Compared to the conventional pairing of control and treated samples in the avoidance tests, the pairing of the different treated samples with each other proved to be a more sensitive method to assess preference behavior, so this method could provide us additional information in forecasting the effects of different soil amendments on potworms.

The ecotoxicity test results with E. albidus showed that bauxite residue at low concentrations $(\leq 5 \%)$ may be used as soil amendment as it provides a better habitat for these organisms. 


\section{Acknowledgments}

We would like to thank the Institute for Soil Sciences and Agricultural Chemistry, Centre for Agricultural Research, Hungarian Academy of Sciences for data on soil analysis. We are thankful to Dr. Sándor Kemény and Éva Pusztai for the help with statistical analysis. We would like to thank Benjámin Kulcsár for his help with the laboratory works. We would like to thank Illés Patányi for the Allplan 2014 Figure. We are thankful to Emese Vaszita for language editing of the manuscript.

\section{References}

[1] Graefe, U., Schmelz, R. M. "Indicator values, strategy types and life forms of terrestrial Enchytraeidae and other microannelids", Newsletter on Enchytraeidae, 6, pp. 59-67, 1999, [online] Available at: http://www.ifab-hamburg.de/documents/GraefeSchmelz1999. pdf [Accessed: 10 August 2018]

[2] Römbke, J. "Ecotoxicological laboratory tests with enchytraeids: A review: The 7th international symposium on earthworm ecology Cardiff Wales 2002", Pedobiologia, 47(5-6), pp. 607-616, 2003. https://doi.org/10.1078/0031-4056-00235

[3] Coleman, D. C., Wall, D. H. "Chapter 5 - Soil Fauna: Occurrence, Biodiversity and Roles in Ecosystem Function", In: Paul, E. A. (ed.) Soil Microbiology, Ecology and Biochemistry, 4th ed., Academic Press, Boston, USA, 2015, pp. 111-149. https://doi.org/10.1016/B978-0-12-415955-6.00005-0

[4] Rutgers, M., Mulder, C., Schouten, A. J. (eds.) "Soil ecosystem profiling in the Netherland with ten references for biological soil quality", RIVM, Bilthoven, The Netherlands, Rep. 607604009/2008, 2008, [online] Available at: http://edepot.wur.nl/35859 [Accessed: 10 August 2018]

[5] Didden, W. A. M. "Population ecology and functioning of Enchytraeidae in some arable farming systems", Doctoral thesis, Agricultural University, Wageningen, The Netherlands, 1991, [online] Available at: http://edepot.wur.nl/202864 [Accessed: 10 August 2018]

[6] Didden, W. A. M. "Ecology of terrestrial Enchytraeidae", Pedobiologia, 37, pp. 2-29, 1993.

[7] Didden, W. , Römbke, J. "Enchytraeids as Indicator Organisms for Chemical Stress in Terrestrial Ecosystems", Ecotoxicology and Environmental Safety, 50(1), pp. 25-43, 2001.

https://doi.org/10.1006/eesa.2001.2075

[8] Weuffen, W. "Zusammenhänge zwischen chemischer Konstitution und keimwidriger Wirkung. 20. Verminoxe Eigenschaften einiger Benzylisothiocyanate, geprüft am Modell des Enchyträentests", (Relation between Chemical Constitution and Germicidal Activity. 20. Anthelmintic Properties of Various Benzyl Isothiocyanates Tested on the Model of Enchytraeus Test) Archiv für Experimentelle Veterinärmedizin, 22(1), pp. 127-132, 1968. (in German)
We are grateful for the financial support of the National Research, Development and Innovation Office OTKA PD 115871 and 121172 projects. This work was supported by the Higher Education Excellence Program of the Ministry of Human Capacities in the frame of Biotechnology research area of Budapest University of Technology and Economics (BME FIKP-BIO).

[9] Natal da Luz, T., Ribeiro, R., Sousa, J. P. "Avoidance tests with collembola and earthworms as early screening tools for site specific assessment of polluted soils", Environmental Toxicology and Chemistry, 23(9), pp. 2188-2193, 2004. https://doi.org/10.1897/03-445

[10] Aldaya, M. M., Lors, C., Salmon, S., Ponge, J.-F. "Avoidance bio-assays may help to test the ecological significance of soil pollution", Environmental Pollution, 140(1), pp. 173-180, 2006. https://doi.org/10.1016/j.envpol.2005.06.011

[11] Loureiro, S., Amorim, M. J. B., Campos, B., Rodrigues, S. M. G., Soares, A. M. V. M. "Assessing joint toxicity of chemicals in Enchytraeus albidus (Enchytraeidae) and Porcellionides pruinosus (Isopoda) using avoidance behaviour as an endpoint", Environmental Pollution, 157(2), pp. 625-636, 2009. https://doi.org/10.1016/j.envpol.2008.08.010

[12] Amorim, M. J. B., Römbke, J., Soares, A. M. V. M. "Avoidance behaviour of Enchytraeus albidus: Effects of Benomyl, Carbendazim, phenmedipham and different soil types", Chemosphere, 59(4), pp. 501-510, 2005. https://doi.org/10.1016/j.chemosphere.2005.01.057

[13] ASTM E1676 - 12 "Standard Guide for Conducting Laboratory Soil Toxicity or Bioaccumulation Tests with the Lumbricid Earthworm Eisenia fetida and the Enchytraeid Potworm Enchytraeus albidus", ASTM International, West Conshohocken, Pennsylvania, USA, 2012, [online] Available at: https://www.astm.org/Standards/ E1676.htm [Accessed: 10 August 2018]

[14] OECD "Test No. 220:Enchytraeid Reproduction Test", In: OECD Guidelines for the Testing of Chemicals, Section 2, Effects on Biotic Systems, OECD Publishing, 2016. https://doi.org/10.1787/20745761

[15] Australian Aluminium Council LTD "World Aluminium, Bauxite Residues Management: Best Practice", 2004, [online] Available at: http://aluminium.org.au/_literature_175772/Bauxite_Residue_ Management_-_Best_Practice_(IAI) [Accessed: 03 April 2005]

[16] Gräfe, M., Power, G., Klauber, C. "Bauxite residue issues: III. Alkalinity and associated chemistry", Hydrometallurgy, 108(1-2), pp. 60-79, 2011. https://doi.org/10.1016/j.hydromet.2011.02.004 
[17] Power, G., Gräfe, M., Klauber, C. "Bauxite residue issues: I. Current management, disposal and storage practices", Hydrometallurgy, 108(1-2), pp. 33-45, 2011.

https://doi.org/10.1016/j.hydromet.2011.02.006

[18] Mayes, W. M., Jarvis, A. P., Burke, I. T., Walton, M., Feigl, V., Klebercz, O., Gruiz, K. "Dispersal and Attenuation of Trace Contaminants Downstream of the Ajka Bauxite Residue (Red Mud) Depository Failure, Hungary", Environmental Science and Technology, 45(12), pp. 5147-5155, 2011.

http://doi.org/10.1021/es200850y

[19] Klebercz, O., Mayes, W. M., Anton, Á. D., Feigl, V., Jarvis, A. P., Gruiz, K. "Ecotoxicity of fluvial sediments downstream of the Ajka red mud spill, Hungary", Journal of Environmental Monitoring, 14(8), pp. 2063-2071, 2012.

http://doi.org/10.1039/c2em30155e

[20] Renforth, P., Mayes, W. M., Jarvis, A. P., Burke, I. T., Manning, D. A. C., Gruiz, K. "Contaminant mobility and carbon sequestration downstream of the Ajka (Hungary) red mud spill: The effects of gypsum dosing", Science of The Total Environment, 421-422, pp. 253-259, 2012.

https://doi.org/10.1016/j.scitotenv.2012.01.046

[21] Summers, R. N., Pech, J. D. "Nutrient and metal content of water, sediment and soil amended with bauxite residue in the catchment of the Peel Inlet and Harvey Estuary, Western Australia", 64(3), pp. 219-232, 1997. https://doi.org/10.1016/S0167-8809(97)00040-6

[22] Ujaczki, É., Feigl, V., Farkas, É., Vaszita, E., Gruiz, K., Molnár, M. "Red mud as acidic sandy soil ameliorant: a microcosm incubation study", Journal of Chemical Technology and Biotechnology, 91(6), pp. 1596-1606, 2016 https://doi.org/10.1002/jctb.4898

[23] Garau, G., Castaldi, P., Santona, L., Deiana, P., Melis, P. "Influence of red mud, zeolite and lime on heavy metal immobilization, culturable heterotrophic microbial populations and enzyme activities in a contaminated soil", Geoderma, 142(1-2), pp. 47-57, 2007. https://doi.org/10.1016/j.geoderma.2007.07.011

[24] Castaldi, P., Melis, P., Silvetti, M., Deiana, P., Garau, G. "Influence of pea wheat growth on $\mathrm{Pb}, \mathrm{Cd}$ and $\mathrm{Zn}$ mobility and soil biological status in a polluted amended soil", Geoderma, 151(3-4), pp. 241-248, 2009.

https://doi.org/10.1016/j.geoderma.2009.04.009

[25] Feigl, V., Anton, A., Uzinger, N., Gruiz, K. "Red Mud as a Chemical Stabilizer for Soil Contaminated with Toxic Metals", Water, Air, and Soil Pollution, 223(3), pp. 1237-1247, 2012. http://doi.org/10.1007/s11270-011-0940-4

[26] Gruiz, K., Meggyes, T., Fenyvesi, É. "Engineering Tools for Environmental Risk Management: 2. Environmental Toxicology", 1st ed., CRC Press, Leiden, The Netherlands, 2015.

[27] Winkler, D. "Collembolan response to red mud pollution in Western Hungary", Applied Soil Ecology, 83, pp. 219-229, 2014. https://doi.org/10.1016/j.apsoil.2013.07.006

[28] Rékási, M., Feigl, V., Uzinger, N., Gruiz, K., Makó, A., Anton, A. "Effects of leaching from alkaline red mud on soil biota: modelling the conditions after the Hungarian red mud disaster", Chemistry and Ecology, 29(8), pp. 709-723, 2013.

https://doi.org/10.1080/02757540.2013.817568
[29] Ujaczki, É., Klebercz, O., Feigl, V., Molnár, M., Magyar, Á., Uzinger, N., Gruiz, K. "Environmental Toxicity Assessment of the Spilled Ajka Red Mud in Soil Microcosms for Its Potential Utilization as Soil Ameliorant", Periodica Polytechnica Chemical Engineering, 59(4), pp. 253-261, 2015.

https://doi.org/10.3311/PPch.7839

[30] Maddocks, G., Reichelt-Brushett, A., McConhie, D., Vangronsveld, J. "Bioaccumulation of metals in Eisenia fetida after exposure to a metal-loaded BauxolTM reagent", Environmental Toxicology and Chemistry, 24(3), pp. 554-563, 2005.

https://doi.org/10.1897/04-087R.1

[31] Courtney, R., O'Neill, N., Harrington, T., Breen, J. "Macroathropod succession in grassland growing on bauxite residue", Ecological Engineering, 36(12), pp. 1666-1671, 2010. https://doi.org/10.1016/j.ecoleng.2010.07.006

[32] de Barros Amorim, M. J., Römbke, J., Schallnaß, H.-J., Soares, A. M. V. M. "Effect of soil properties and aging on the toxicity of copper for Enchytraeus albidus, Enchytraeus luxuriosus, and Folsomia candida", Environmental Toxicology and Chemistry, 24(8), pp. 1875-1885, 2005.

https://doi.org/10.1897/04-505R.1

[33] "HS 21470-50 Environmental testing of soils. Determination of total and soluble toxic element, heavy metal and chromium(VI) content", Hungarian Standard, 2006, [online] Available at: http:// www.mszt.hu/ [Accessed: 10 August 2018]

[34] "HS 21978-9 Investigation of hazardous waste. Extract for physical-, chemical and toxicological", Hungarian Standard, 1998, [online] Available at: http://www.mszt.hu/ [Accessed: 10 August 2018]

[35] "HS 08-0205 Determination of Physical and Hydrophysical Properties of Soils", Hungarian Standard, 1978, [online] Available at: http://www.mszt.hu/ [Accessed: 10 August 2018]

[36] Öhlinger, R., Kandeler, E. "Methods in Soil Physics", In: Schinner, F., Öhlinger, R., Kandeler, E., Margesin, R. (eds.) Methods in Soil Biology, Springer-Verlag, Berlin, Germany, 1996, pp. 385-395.

https://doi.org/10.1007/978-3-642-60966-4_28

[37] "HS 21470-2 Environmental protection. Preparation of soil sample. Determination of electrical conduction, humidity and $\mathrm{pH}$, Hungarian Standard, 1981, [online] Available at: http://www.mszt. hu/ [Accessed: 10 August 2018]

[38] "HS 08-0206-2 Evaluation of some chemical properties of the soil. Laboratory tests. $(\mathrm{pH}$ value, phenolphtaleine alkalinity expressed in soda, all water soluble salts, hydrolite ( $\mathrm{y}^{\vee} 1^{\wedge}$-value) and exchanging acidity ( $\mathrm{y}^{` 2} 2^{\wedge}$ - value)", Hungarian Standard, 1978, [online] Available at: http://www.mszt.hu/ [Accessed: 10 August 2018]

[39] OECD "Test No. 207:Earthworm, Acute Toxicity Tests", In: OECD Guidelines for the Testing of Chemicals, Section 2, Effects on Biotic Systems, OECD Publishing, 1984. https://doi.org/10.1787/20745761

[40] Amorim, M. J. B., Novais, S., Römbke, J., Soares, A. M. V. M. "Enchytraeus albidus (Enchytraeidae): A test organism in a standardised avoidance test? Effects of different chemical substances", Environmental International, 34(3), pp. 363-371, 2008. https://doi.org/10.1016/j.envint.2007.08.010 
[41] Feigl, V., Ujaczki, É., Vaszita, E., Molnár, M. "Influence of red mud on soil microbial communities: Application and comprehensive evaluation of the Biolog EcoPlate approach as a tool in soil microbiological studies", Science of The Total Environment, 595, pp. 903-911, 2017.

https://doi.org/10.1016/j.scitotenv.2017.03.266

[42] Stefanovits, P., Filep, Gy., Füleky, Gy. "Talajtan", (Soil Science) Mezőgazda Kiadó, Budapest, Hungary, 1999. (in Hungarian)

[43] 6/2009 (IV. 14.) KvVM-EüM-FVM "együttes rendelet a földtani közeg és a felszín alatti víz szennyezéssel szembeni védelméhez szükséges határértékekröl és a szennyezések méréséröl", (decree laying down limits necessary for the protection of geological medum and groundwater against pollution and on measurements of pollutants) KvVM-Eüm-FVM (Hungarian ministries), Budapest, Hungary, 2009 (in Hungarian), [online] Available at: https://net.jogtar.hu/jogszabaly?docid=a0900006.kvv [Accessed: 10 August 2018]

[44] Snars, K. E., Gilkes, R. J., Wong, M. T. F. "The liming effect of bauxite processing residue (red mud) on sandy soils", Australian Journal of Soil Research, 42(3), pp. 321-328, 2004. https://doi.org/10.1071/SR03021

[45] Swartjes, F. A. "Risk-Based Assessment of Soil and Groundwater Quality in the Netherlands: Standards and Remediation Urgency", Risk Analysis, 19(6), pp. 1235-1249, 1999. https://doi.org/10.1111/j.1539-6924.1999.tb01142.x

[46] Burke, I. T., Peacock, C. L., Lockwood, C. L., Stewart, D. I., Mortimer, R. J., G., Ward, M. B., Renforth, P., Gruiz, K., Mayes, W. M. "Behavior of Aluminium, Arsenic and Vanadium during the Neutralization of Red Mud Leachate by HCl, Gypsum or Seawater", Environmental Science and Technology, 47(12), pp. 6527-6535, 2013. http://doi.org/10.1021/es4010834

[47] Ghosh, I., Guha, S., Balasubramaniam, R., Kumar, A. V. R. "Leaching of metals from fresh and sintered red mud", Journal of Hazardous Materials, 185(2-3), pp. 662-668, 2011. https://doi.org/10.1016/j.jhazmat.2010.09.069

[48] Rubinos, D., Spagnoli, G., Barral, M. T. "Assessment of bauxite refining residue (red mud) as a liner for waste disposal facilities", International Journal of Mining, Reclamation and Environment, 29(6), pp. 433-452, 2013 https://doi.org/10.1080/17480930.2013.830906

[49] Anton, A., Rékási, M., Uzinger, N., Széplábi, G., Makó, A. "Modelling the Potential Effects of the Hungarian Red Mud Disaster on Soil Properties", Water, Air, and Soil Pollution, 223(8), pp. 5175-5188, 2012. http://doi.org/10.1007/s11270-012-1269-3

[50] Renforth, P., Mayes, W. M., Javis, A. P., Burke, I. T., Manning, D. A. C., Gruiz, K. "Contaminant mobility and carbon sequestration downstream of the Ajka (Hungary) red mud spill: The effects of gypsum dosing", Science of The Total Environment, 421-422, pp. 253-259, 2012.

https://doi.org/10.1016/j.scitotenv.2012.01.046

[51] Samal, S., Ray, A. K., Bandopadhyay, A. "Proposal for resources, utilization and processes of red mud in India - A review", International Journal of Mineral Processing, 118, pp. 43-55, 2013. https://doi.org/10.1016/j.minpro.2012.11.001
[52] Mayes, W. M., Burke, I. T., Gomes, H. I., Anton, Á. D., Molnár, M., Feigl, V., Ujaczki, É. "Advances in Understanding Environmental Risks of Red Mud After the Ajka Spill, Hungary", Journal of Sustainable Metallurgy, 2(4), pp. 332-343, 2016. http://doi.org/10.1007/s40831-016-0050-z

[53] Gruiz, K., Fekete-Kertész, I., Kunglné-Nagy, Zs., Hajdu, Cs., Feigl, V., Vaszita, E., Molnár, M. "Direct toxicity assessment - Methods, evaluation, interpretation", Science of The Total Environment, 563-564, pp. 803-812, 2016. https://doi.org/10.1016/j.scitotenv.2016.01.007

[54] Sydow, M., Chrzanowski, Ł., Cedergreen, N., Owsianiak, M. "Limitations of experiments performed in artificially made OECD standard soils for predicting cadmium, lead, and zinc toxicity towards organisms living in natural soil", Journal of Environmental Management, 198(2), pp. 32-40, 2017. http://doi.org/10.1016/j.jenvman.2017.04.092

[55] Kuperman, R. G., Amorim, M. J. B., Römbke, J., Lanno, R., Checkai, R. T., Dodard, S. G., Sunahara, G. I., Scheffczyk, A. "Adaptation of the enchytraeid toxicity test for use with natural soil types", European Journal of Soil Biology, 42(Supplement 1), pp. S234-S243, 2006. https://doi.org/10.1016/j.ejsobi.2006.07.028

[56] Jänsch, S., Amorim, M. J., Römbke, J. "Identification of the ecological requirements of important terrestrial ecotoxicological test species", Environmental Reviews, 13(2), pp. 51-83, 2005. https://oi.org/10.1139/a05-007

[57] Lock, K., Janssen, C. R. "Effect of clay and organic matter type on the ecotoxicity of zinc and cadmium to the potworm Enchytraeus albidus", Chemosphere, 44(8), pp. 1669-1672, 2001. https://doi.org/10.1016/S0045-6535(00)00565-8

[58] Novais, S. C., Gomes, I. L., Gravato, C., Guilhermino, L., De Coen, W., Soares, A. M. V. M., Amorim, M. J. B. "Reproduction and biochemical responses in Enchytraeus albidus (Oligochaeta) to zinc or cadmium exposures", Environmental Pollution, 159(7), pp. 1836-1843, 2011. https://doi.org/10.1016/j.envpol.2011.03.031

[59] Lock, K., Janssen, C. R. "Comparative toxicity of a zinc salt, zinc powder and zinc oxide to Eisenia fetida, Enchytraeus albidus and Folsomia candida", Chemosphere, 53(8), pp. 851-856, 2003. https://doi.org/10.1016/S0045-6535(03)00593-9

[60] Amorim, M. J. de B., Römbke, J., Schallnaß, H.-J., Soares, A. M. V. M. "Effect of soil properties and aging on the toxicity of copper for Enchytraeus albidus, Enchytraeus luxuriosus, and Folsomia candida", Environmental Toxicology and Chemistry, 24(8), pp. 1875-1885, 2005. https://oi.org/10.1897/04-505R.1

[61] Lock, K., Janssen, C. R. "Multi-generation toxicity of zinc, cadmium, copper, and lead to the potworm Enchytraeus albidus", Environmental Pollution, 117(1), pp. 89-92, 2002. http://doi.org/10.1016/S0269-7491(01)00156-7

[62] Lock, K., Janssen, C. R. "Ecotoxicity of Chromium (III) to Eisenia fetida, Enchytraeus albidus, and Folsomia candida", Ecotoxicology and Environmental Safety, 51(3), pp. 203-205, 2002. https://doi.org/10.1006/eesa.2001.2122 
[63] Lock, K., Janssen, C. R. "Ecotoxicity of nickel to Eisenia fetida, Enchytraeus albidus and Folsomia candida", Chemosphere, 46(2), pp. 197-200, 2002.

https://doi.org/10.1016/S0045-6535(01)00112-6

[64] Gomes, S. I. L., Scott-Fordsmand, J. J., Amorim, M. J. B. "Profiling transcriptomic response of Enchytraeus albidus to $\mathrm{Cu}$ and Ni: Comparison with $\mathrm{Cd}$ and $\mathrm{Zn} "$, Environmental Pollution, 186, pp. 75-82, 2014

https://doi.org/10.1016/j.envpol.2013.11.031

[65] Yeardley Jr., R. B., Gast, L. C., Lazorchak, J. M. "The potential of an eartworm avoidance test for evaluation of hazardous waste sites", Society of Environmental Toxicology and Chemistry, 15(9), pp. 1532-1537, 1996.

http://doi.org/10.1002/etc.5620150915

[66] De Silva, P. M. C. S., van Gestel, C. A. M. "Comparative sensitivity of Eisenia andreai and Perionyx excavatus in earthworm avoidance tests using two soil types in the tropics", Chemosphere, 77(11), pp. 1609-1613, 2009.

https://doi.org/10.1016/j.chemosphere.2009.09.034
[67] Amorim, M. J. B., Oliveira, E., Teixeira, A. S., Gravato, C. S., Loureiro, S., Guilhermino, L. C., Van Gestel, C. A. M., Soares, A. M. V. M. "Toxicity and bioaccumulation of phenanthrene in Enchytraeus albidus (Oligochaeta: Enchytraeidae)", Environmental Toxicology and Chemistry, 30(4), pp. 967-972, 2011.

https://doi.org/10.1002/etc.464

[68] Barmentlo, S. H., van Gestel, C. A. M., Álvarez-Rogel, J. GonzálezAlcaraz, M. N. "Influence of climate change ont he multi-generation toxicity to Enchytraeus crypticus of soils polluted by metal/metalloid mining wastes", Environmental Pollution, 222, pp. 101-108, 2017. https://doi.org/10.1016/j.envpol.2016.12.078

[69] Moser, H., Römbke, J. "Ecotoxicological Characterization of Waste, Results and Experiences of an International Ring Test", 1st ed., Springer-Verlag, New York, USA, 2009. 